17. Felzer AB Dobronevskyi OV. Technique of work of the head. Kiev: Vyshcha Shkola; 2019. $408 \mathrm{~s}$.

18. Mintzberg H.The Rise and Fall of Strategic Planning in physical rehabilitation. New York: Free Press, 2018: 54-72.

19. Hart S., Banbury C. Now Strategy Making Process Can Make a Difference, Strategis Management. 2019: 34-58.

20. Marline D. Choice Situation, Strategi, and Performance: A Reexamination,, Strategis Management. 2020: 76-92.

Цитування на цю статтю:

Тягур РС, Мисів ВМ, Матійчук IB. Менеджер у фізичній культурі: планування особистої діяльності. Вісник Прикарпатського університету. Серія: Фізична культура. 2020 Листоп 24; 36: 74-86

\begin{tabular}{|c|c|}
\hline Відомості про автора: & Information about the author: \\
\hline $\begin{array}{l}\text { Tягур Роман Степанович - кандидат педагогічних } \\
\text { наук, доцент, ДВНЗ “Прикарпатський національ- } \\
\text { ний університет імені Василя Стефаника” (Івано- } \\
\text { Франківськ, Україна) }\end{array}$ & $\begin{array}{l}\text { Tiahur Roman Stepanovych - Candidate of Science } \\
\text { (Education), Associate Professor (Ph. D.), Vasyl Ste- } \\
\text { fanyk Precarpathian National University (Ivano-Fran- } \\
\text { kivsk, Ukraine) }\end{array}$ \\
\hline \multicolumn{2}{|l|}{$\begin{array}{l}\text { e-mail: tyagur.roman@ gmail.com } \\
\text { https://orcid.org/0000-0002-7722-7938 }\end{array}$} \\
\hline $\begin{array}{l}\text { Мисів Володимир Михайлович - кандидат наук } 3 \\
\text { фізичного виховання та спорту, доцент, Кам’янець- } \\
\text { Подільський національний університет імені Івана } \\
\text { Огієнка (Кам'янець-Подільський, Україна) }\end{array}$ & $\begin{array}{l}\text { Mysiv Volodymyr Mykhailovych - Candidate of } \\
\text { Science (Physical Education and Sport), Associate } \\
\text { Professor (Ph. D.), Kamianets-Podilskyi National Ivan } \\
\text { Ohiienko University (Kamianets-Podilskyi, Ukraina) }\end{array}$ \\
\hline \multicolumn{2}{|l|}{$\begin{array}{l}\text { e-mail: mysiv@kpnu.edu.ua } \\
\text { https://orcid.org/0000-0003-1957-0241 }\end{array}$} \\
\hline $\begin{array}{l}\text { Матійчук Ігор Васильович - професор кафедри } \\
\text { спортивно-педагогічних дисциплін, ДВНЗ “При- } \\
\text { карпатський національний університет імені Ва- } \\
\text { силя Стефаника" (Івано-Франківськ, Україна) }\end{array}$ & $\begin{array}{l}\text { Matiichuk Ihor Vasylovych - Professor of the } \\
\text { Department of Sports and Pedagogical Disciplines, } \\
\text { Vasyl Stefanyk Precarpathian National University } \\
\text { (Ivano-Frankivsk, Ukraine) }\end{array}$ \\
\hline $\begin{array}{l}\text { e-mail: ihor.matiichuk@ pnu.edu.ua } \\
\text { https://orcid.org/0000-0002-9379-7981 }\end{array}$ & \\
\hline
\end{tabular}

УДК 378.014.6.093.5:796 doi: $10.15330 / f c u l t .36 .86-94$

\section{Сергій Черненко, Олег Олійник,} Юрій Сорокін, Олег Коваль

\title{
ХАРАКТЕРИСТИКА ОСВІТНЬОГО ПРОЦЕСУ ПІДГОТОВКИ МАЙБУТНІХ ФХІВЦІВ 3 ФІЗИЧНОЇ КУЛЬТУРИ І СПОРТУ
}

Мета. Встановити системність підготовки майбутніх тренерів- викладачів у закладі вищої освіти. Методи. У дослідженні взяли участь 30 студентів першого і 20 другого курсів. Вибір методів, щзо використані в статті, обумовлений логічною моделлю прочесу дослідження, щзо склалася в педагогічній науці. Теоретичний аналіз науково-методичної літератури проводився для вивчення основних концепцій управління підготовки майбутніх фахівц̧ів зі спеціальності 017 - фізична культура $i$ спорт. Вивчення педагогічної та навчально-нормативної документації вищої школи дало змогу встановити проблеми в розумінні студентів процесу освіти в галузі фізичної культури. Анкетування, констатуючий експеримент, методи математичної статистики (графічне відображення даних, аналіз параметрів розподілу) дозволили визначити стан підготовки майбутніх викладачів фізичного виховання у вищому навчальному закладі. Результати. Встановлено, щзо професійно-педагогічна підготовка тренера-викладача спрямована на формування наступних компонентів: мотиваційно-педагогічного (відображає спрямованість, мотиви, потреби в навчанні, иіннісні орієнтації), когнітивно-педагогічного (знання вікової психології, вікових морфо-функціональних особливостей людини), конструктивно-педагогічного (формуванням цілей діяльності, складанням планів і програм, плануванням занять із фізичного виховання і спорту), організаційно-педагогічного (здатність $і$ готовність організовувати навчальнотренувальний процес, управляти і моніторити його ефективність), педагогічно-технологічного (психолого-педагогічні вміння та навички розв 'язувати завдання спортивного тренування дітей і підлітків) та педагогічно-рефлексивного (вміння вивчати, адаптувати і застосовувати кращий досвід в управлінні фізичною підготовкою). Найбільший вплив на професійно-педагогічну мотивацію студентів першого $i$

(C) Черненко С., Олійник О., Сорокін Ю.,

Коваль О., 2020 
Черненко Сергій, Олійник Олег, Сорокін Юрій, Коваль Олег. Характеристика освітнього процесу ...

другого курсів чинять дисципліни, розташовані у загально-професійному та професійному блочі. Виявлений низький рівень зацікавленості студентів у здійсненні науково-дослідницької діяльності. Висновок. Встановлено, щчо для здобуття освітньої кваліфікації тренер-викладач на початкових етапах навчання (1-2 курси) для студентів найважливішими є дисципліни професійної підготовки.

Ключові слова: професійно-педагогічні компетентності, навчальні дисципліни, студенти.

The purpose is to determine the systematic PE future teachers training in higher education institutions. Material and research methods: The study involved 30 first-year and 20 second-year students. The choice of methods used in the article is determined by the logical model of the research process that was developed in pedagogical science. Theoretical analysis of scientific and methodological literature was conducted to study the basic concepts of future specialists training management in the specialty of physical culture and sports. The study of pedagogical, educational and regulatory documentation of higher education has allowed us to identify problems in the students' understanding of the educational process in the field of physical culture. Questionnaires, ascertaining experiments, mathematical statistics methods (graphical data display, distribution parameters analysis) allowed us to determine the state of future PE teachers training in higher education institutions. The study determined that the professional pedagogical coach-teachers training is aimed at the following components formation: motivational and pedagogical (reflects the direction, motivation, training needs, value orientations), cognitive-pedagogical (knowledge of age psychology, human's age-related morpho-functional characteristics), structural and pedagogical (formation of goals and objectives, plans and programs, planning sessions in physical education and sport), organizational and pedagogical (the ability and willingness to organize training process, to manage and monitor its effectiveness), pedagogical and technological (psychological and pedagogical skills and skills to solve problems in children and adolescents' sports training) and pedagogical and reflexive (the ability to study, adapt and apply the best experience in physical training management). The greatest influence on professional and pedagogical motivation of first- and second-year students is provided by disciplines of general professional and professional block. The low level of students ' interest in research activities is revealed. It is established that for obtaining educational qualification of a coach-teacher at the initial stages of training (1-2 courses), the most important subjects for students are professional training.

Keywords: professional and pedagogical competencies, academic disciplines, students.

Постановка проблеми та аналіз результатів останніх досліджень. Головною метою системи фізичної культури науковці вважають формування цілісної особистості, що передбачає активний вплив не лише на ії̈ фізичний потенціал, а й на когнітивний та емоційний інтелект, а відтак формуванні стійкої позитивної мотивації, ціннісних орієнтацій, інтересів і потреб у фізичній активності та здоровому способі життя $[1,2,3]$. Актуальність дослідження спричинена:

- об’єктивною важливістю проблеми професійної підготовки тренерів-викладачів у закладах вищої освіти (ЗВО) і станом їі розв'язання в педагогічній науці та практиці;

- проблемною ситуацією, пов'язаною з невідповідністю змісту, форм і методів підготовки тренерів-викладачів до професійної діяльності;

- відсутністю системного зв'язку між педагогічними теоріями і практикою підготовки тренерів - викладачів.

Проблеми професійної підготовки тренерів-викладачів були предметом дослідження багатьох науковців [4, 5, 6, 7]. Проте, підписання Болонської конвенції актуалізувало низку інновацій у системі вищої освіти України, серед яких компетентнісний підхід, що є одним із концептуально важливих засобів управління якістю підготовки майбутніх фахівців зі спеціальності 017 - фізична культура і спорт.

Розглядаючи питання про професійну підготовленість тренерів-викладачів з урахуванням компетентнісного підходу, дослідники зазначають, що це комплекс професійно-педагогічних компетентностей, котрі формуються як на теоретичних заняттях, так і в процесі практичної спортивно-педагогічної підготовки, а також під час тренерської і педагогічної практик, де студенти виступають у ролі тренерів, вчителів, керів- 
ників спортивних секцій, організаторів оздоровчо-спортивних заходів в закладах середньої освіти і дитячо-юнацьких спортивних школах [8].

Щоб визначити стан професійної підготовки тренерів-викладачів у ЗВО необхідно перш за все визначити поняття, критерії, показники та рівні сформованості професійно-педагогічних компетентностей. ності:

Відомі фахівці $[9,10]$ визначають наступні професійно-педагогічні компетент-

- мотиваційно-педагогічний компонент (відображає спрямованість, мотиви, потреби в навчанні, ціннісні орієнтації викладача, а також готовність до стимулювання в учнів рухової активності, фізичного самовдосконалення);

- когнітивно-педагогічний компонент (охоплює знання предмета “фізичної культура", вікової психології, вікових морфо-функціональних та індивідуальних особливостей)

- сутності й ознак навчальної діяльності, специфіки інноваційних технологій навчання у фізичній культурі;

- творчо-педагогічний компонент пов'язаний із формуванням цілей діяльності, складанням планів і програм, плануванням занять, відбору цілеспрямованих видів діяльності учнів, пошуку необхідних засобів, методів, врахування умов перебігу освітнього процесу.

- організаційно-педагогічний компонент охоплює здатність і готовність тренеравикладача належним чином організовувати навчально-тренувальний процес, управляти ним i здійснювати моніторинг його ефективності, вчасно виявляючи недоліки. Це передбачає вміння викладача залучати учнів до різних видів діяльності.

- педагогічно-технологічний компонент компетентності відображає психологопедагогічні вміння та навички, що забезпечують послідовне й оптимальне розв'язання завдань спортивного тренування дітей і підлітків.

- педагогічно-рефлексивний компонент тренера-викладача передбачає вміння вивчати, адаптувати і застосовувати кращий досвід в управлінні фізичною підготовкою, дослідницькі вміння та навички добирати продуктивні форми, засоби і методи спортивного тренування, проводити експериментальні дослідження та робити аргументовані висновки на основі одержаних результатів.

На основі характеристики компонентів професійно-педагогічної компетентності H.I. Степанченко [11] пропонує наступні критерії ефективності системи професійної підготовки тренерів-викладачів: вмотивованість (діагностичні зрізи змін професійної мотивації студентів); навченість (порівняння успішності студентів із загальних та фахових дисциплін); вправність (динаміка змін самооцінки педагогічних умінь у студентів); практична спрямованість (динаміка змін практичних педагогічних умінь у студентів); результативність (порівняння результатів випускного оцінювання студентів), рефлексивність (зміни показників спрямованості особистості студентів); умотивованість викладачів (динаміки розвитку професійно-педагогічної мотивації у викладачів); рефлексивність викладачів (зміна рівня вдоволення викладачів власною педагогічною діяльністю); майстерність викладачів (динаміка оцінювання студентами професійнопедагогічної діяльності викладачів).

На даний час відбувається інтенсивний і творчий процес розробки та удосконалення освітніх програм у відповідності до Державного стандарту зі спеціальності 017 фізична культура і спорт. Ефективність цього процесу в значній мірі залежить від тісної взаємодії викладачів, студентів і стейкхолдерів.

Мета дослідження - визначити системність підготовки майбутніх тренеріввикладачів у закладах вищої освіти. 
Методи дослідження. Для вирішення завдань дослідження застосовані наступні методи дослідження: аналіз наукової літератури, опитування, педагогічний експеримент, методи математичної статистики (графічне відображення даних, аналіз параметрів розподілу). У дослідженні прийняли участь майбутні тренери-викладачі - (30 студентів 1-го і 20 студентів 2-го курсу). Студенти були інформовані про всі особливості дослідження і дали згоду на участь в педагогічному експерименті. Був проведений констатувальний експеримент, який дозволив за допомогою критерію “вмотивованість" (динаміка змін професійної мотивації студентів) визначити ефективність системи підготовки вчителів фізичної культури. Дослідження дало змогу оцінити рівень значущості дисциплін гуманітарної, природничо-наукової, професійної, практичної підготовки та рівень професійно-педагогічної мотивації студентів до набуття компетентностей майбутньої професії. Враховувалися кількість і частота повторень видів діяльності та знання особливостей практичного виконання цих функцій. Результати дослідження значущості навчальних дисциплін аналізувалися, виходячи з таких показників: 0 - 4,0 бали - низький; 4,1 - 7,9 балів - середній рівень; 8,0 - 10,0 балів - високий рівень.

Для всієї вибірки розраховувалося середнє арифметичне:

$$
\text { ДХ }=\frac{\sum \text { дХ }}{n}
$$

де: ДХ - значення показника "динамічна характеристика" студента; $\mathrm{n}$ - кількість студентів. Рівень професійно-педагогічної мотивації вивчався за допомогою методики Т. Дубовіцької [12 ].

Результати. Як видно 3 табл. 1 та рис. 1 для студентів першого курсу вагоме значення для професійної підготовки має цикл дисциплін природничої і практичної підготовки (теорія і методика викладання гімнастики, спортивних ігор, підвищення спортивної майстерності).

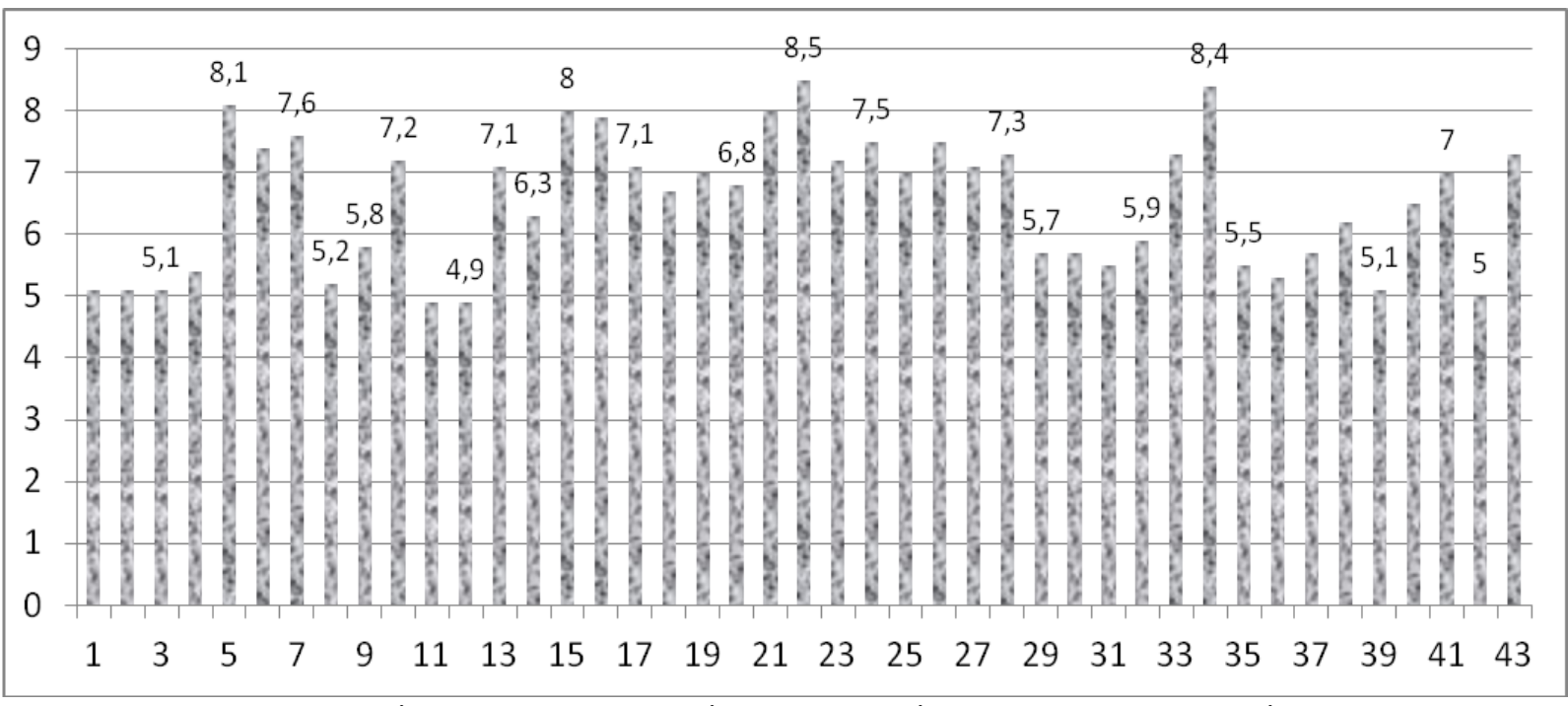

Puc. 1. Гістограма показників значущості навчальних дисциплін

для формування професійних компетентностей у студентів першого курсу:

вісь абсцис - кодування навчальної дисципліни (наведено в табл. 1); вісь ординат - бали.

Найменші показники отримали навчальні дисципліни "Нові інформаційні технології”, “Основи охорони праці” (4,9 бали). 
Характеристика значущості навчальних дисциплін для студентів першого курсу

Таблиия 1 щодо формування професійних компетентностей

\begin{tabular}{|c|c|c|}
\hline Рівні & Бали & Назви навчальних дисциплін та кодування \\
\hline \multirow[t]{2}{*}{ Високий } & $8,1-10,0$ & $\begin{array}{l}\text { Анатомія людини (5), теорія і методика викладання гімнастики (15), спор- } \\
\text { тивних ігор (16), теорія і методика фізичного виховання(21), теорія і мето- } \\
\text { дика спортивного тренування (22), підвищення спортивної майстерності } 3 \\
\text { обраного виду спорту (34). }\end{array}$ \\
\hline & $7,5-8,0$ & $\begin{array}{l}\text { Фізіологія людини (6), основи медичних знань (10), педагогіка фізичного } \\
\text { виховання і спорту (24), психологія фізичного виховання (26), оздоров } \\
\text { фізична культура (28). }\end{array}$ \\
\hline \multirow{5}{*}{ Середній } & $7,0-7,4$ & $\begin{array}{l}\text { Вступ до спеціальності (13), теорія і методика легкої атлетики (17), } \\
\text { атлетизму (19), загальна педагогіка (23)загальна психологія (25), олімпій- } \\
\text { ський і професійний спорт (27), спортивна медицина (41). }\end{array}$ \\
\hline & $6,5-6,9$ & $\begin{array}{l}\text { Історій фізичної культури (14), теорія і методика викладання плавання } \\
\text { (18), фітнесу (20), рухливих ігор і забав (38), адаптивна фізична культура } \\
\text { (40). }\end{array}$ \\
\hline & $6,0-6,4$ & $\begin{array}{l}\text { Біохімія спорту (9), спортивна метрологія (29), управління фізичною } \\
\text { культурою і спортом (32), теорія і методика викладання єдиноборств (37). }\end{array}$ \\
\hline & $5,0-5,9$ & $\begin{array}{l}\text { Iсторія України (3), іноземна мова (1), українська мова (2), філософія (4), } \\
\text { біохімія (8), основи наукових досліджень (31), теорія і методика лижного } \\
\text { спорту (35), туризму (36), скелелазіння (39), біомеханіка (42). }\end{array}$ \\
\hline & $4,1-4,9$ & Нові інформаційні технології (11), охорона праці (12). \\
\hline Низький & $0-4,0$ & Відсутні \\
\hline
\end{tabular}

У табл. 2 та на рис. 2 надано показники значущості навчальних дисциплін для студентів другого курсу. Аналіз показав, що студенти цього курсу визначають високий рівень значущості для професійної підготовки такі навчальні дисципліни: “Основи медичних знань та долікарська допомога" (8,3 бали) теорії і методики викладання гімнастики, спортивних ігор, плавання, спортивного тренування, підвищення спортивної майстерності, а також теорії і методики фізичної культури та спортивної медицини”.

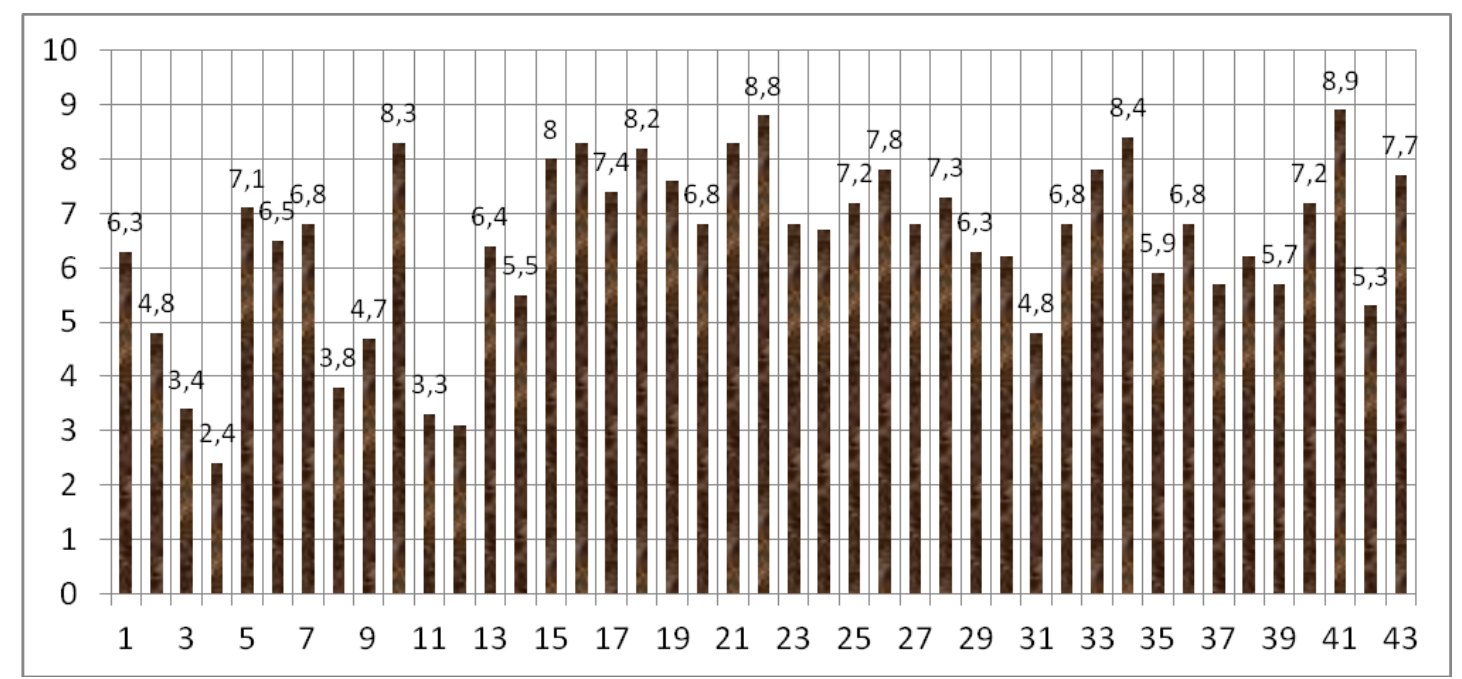

Puc. 2. Гістограма показників значущості навчальних дисциплін для формування професійних компетентностей у студентів другого курсу: вісь абсцис - кодування навчальної дисципліни; вісь ординат - бали.

У студентів другого курсу спостерігається більший перелік дисциплін гуманітарної та природничо-наукової підготовки 3 низьким та середнім рівнем значущості (рис. 2, табл. 2). 
Порівняльний аналіз показників значущості навчальних дисциплін

Таблиия 2

у студентів другого курсу

\begin{tabular}{|c|c|c|}
\hline Рівні & Бали & Назви навчальних дисциплін та кодування \\
\hline \multirow[t]{2}{*}{ Високий } & $8,1-10,0$ & $\begin{array}{l}\text { Основи медичних знань (10), теорія й методика викладання гімнас- } \\
\text { тики (15), спортивних ігор (16), плавання (18), фізичного виховання } \\
(21) \text {, спортивного тренування (22), підвищення спортивної майс- } \\
\text { терності (34), спортивна медицина (41). }\end{array}$ \\
\hline & $7,5-8,0$ & $\begin{array}{l}\text { Теорія і методика викладання легкої атлетики (17), атлетизму (19), } \\
\text { психологія спорту (26), педагогічна практика (33), основи педаго- } \\
\text { гічної майстерності (43). }\end{array}$ \\
\hline \multirow{5}{*}{ Середній } & $7,0-7,4$ & $\begin{array}{l}\text { Анатомія людини (5), загальна психологія (25), оздоровча фізична } \\
\text { культура (28), адаптивне фізична культура (40). }\end{array}$ \\
\hline & $6,5-6,9$ & $\begin{array}{l}\text { Фізіологія людини (6), фізіологія спорту (7), загальна педагогіка (23), } \\
\text { психологія спорту (26), теорія і методика викладання фітнесу (20). }\end{array}$ \\
\hline & $6,0-6,4$ & $\begin{array}{l}\text { Іноземна мова (1), вступ до спеціальності (13), спортивна метрологія } \\
\text { (29), спортивні споруди (30), теорія і методика викладання рухливих } \\
\text { iгор (38). }\end{array}$ \\
\hline & $5,0-5,9$ & $\begin{array}{l}\text { Історія фізичної культури (14), теорія і методика викладання лижного } \\
\text { спорту (35), єдиноборств (37), скелелазіння (39), біомеханіка (42). }\end{array}$ \\
\hline & $4,1-4,9$ & $\begin{array}{l}\text { Українська мова (2), біохімія спорту (9), основи наукових досліджень } \\
\text { (31). }\end{array}$ \\
\hline Низький & $0-4,0$ & $\begin{array}{l}\text { Філософія (4), історія України (3), біохімія (8), нові інформаційні } \\
\text { технології (11), охорона праці (12). }\end{array}$ \\
\hline
\end{tabular}

На рис. 3 подані результати порівняльного аналізу значущості дисциплін у студентів першого і другого курсів. Аналіз показує, що у студентів першого курсу відбувається зростання середньостатистичних показників циклу загальної підготовки: філософія - 5,4 бали; анатомія людини - 8,1 бали; нові інформаційні технології - 4,9 бали.

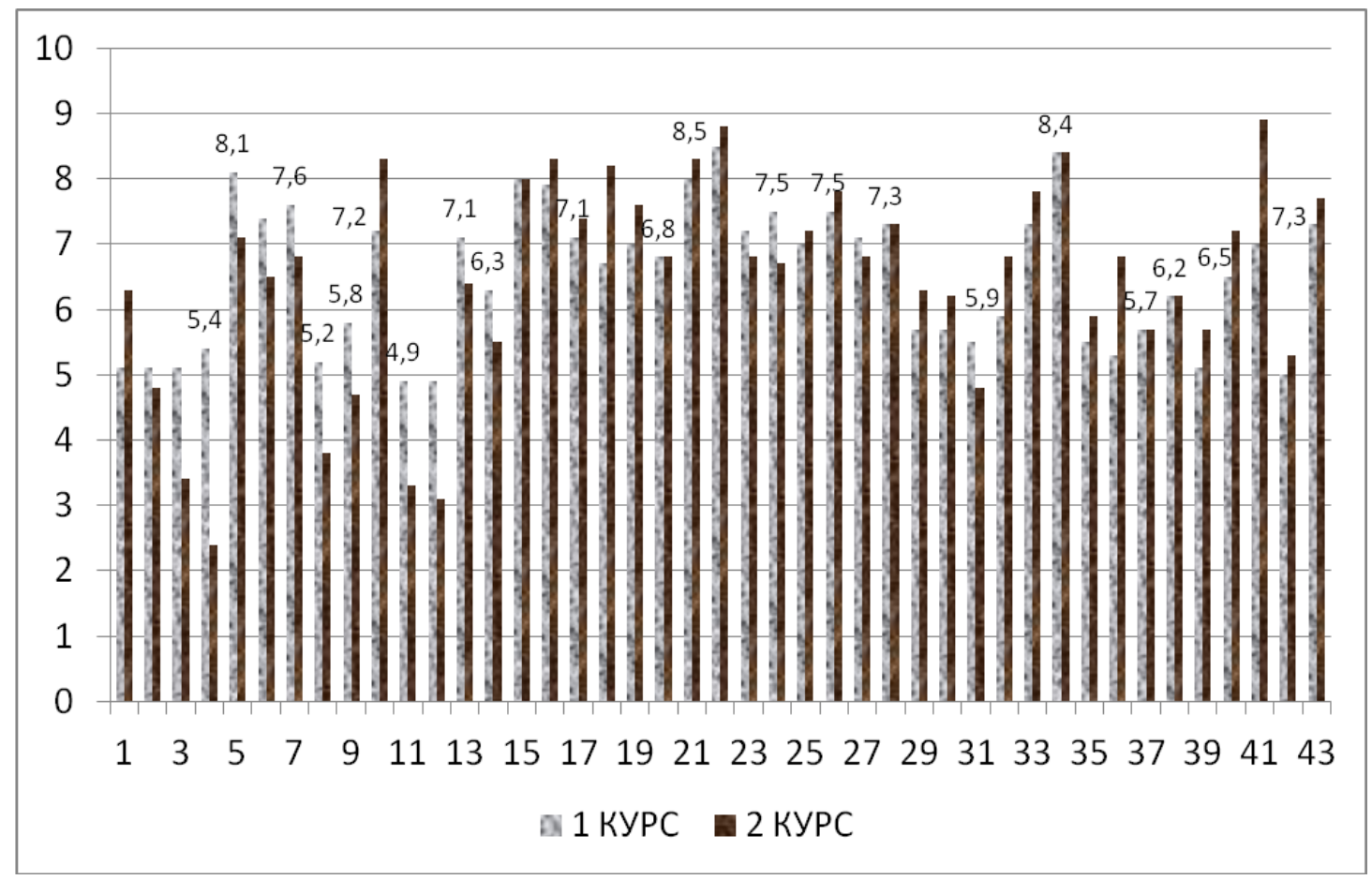

Puc. 3. Порівняльна гістограма показників значущості дисциплін загальної та професійної підготовки серед студентів першого і другого курсів: вісь абсцис - кодування навчальної дисципліни; вісь ординат - бали. 
На другому курсі спостерігаємо зменшення балів $(2,4,7,1,3,3)$, що стосується цих дисциплін. Слід зазначити, що з часом серед студентів другого курсу відбувається зростання значення навчальних дисциплін циклу загальної підготовки (іноземна мова 6,3 бали; основи медичних знань та долікарська допомога - 8,3 бали, а на першому курсі спостерігається зменшення (5,1, 7,2 бали відповідно).

Порівняльний аналіз навчальних дисциплін циклу професійної підготовки засвідчує, що у студентів другого курсу відбувається зростання за наступними предметами: плавання $(8,2)$, туризм $(6,8)$, спортивна медицина $(8,9)$, а на першому курсі значущість є меншою - 6,7, 5,3, 7,0 балів відповідно.

Дискусія. Отримані результати доповнюють відомості $[11,13]$ про динаміку уявлення студентів про професійну діяльність за спеціальністю 017 - фізична культура i спорт, та технології формування готовності майбутніх фахівців фізичної культури [14]. Підтверджено, що знання студентів про майбутню професійну діяльність тренеравикладача орієнтовані, переважно, на дисципліни професійної підготовки $[15,16]$ та спортивно-спеціалізовану діяльність [17]. Водночас у студентів $\epsilon$ низький рівень мотивації до здійснення науково-дослідницької діяльності. Підтримуємо твердження, що діяльність педагога непродуктивна, якщо вона будується лише як відтворення відомих методів роботи і в ній не використовуються науково обгрунтовані дані щодо форм, засобів і методів ефективного тренувального процесу [18].

\section{Висновки.}

1. Професійно-педагогічна підготовка тренера-викладача спрямована на формування наступних компонентів професійної діяльності: мотиваційно-педагогічного, когнітивно-педагогічного, конструктивно-педагогічного, організаційно-педагогічного, педагогічно-технологічного та педагогічно-рефлексивного.

2. Найбільший вплив на формування професійних компетентностей майбутнього тренера-викладача чинять навчальні дисципліни, розташовані у загально-професійному та професійному блоці.

3. Виявлено низький рівень мотивації студентів першого і другого курсів спеціальності 017 - фізична культура і спорт щодо здійснення науково-дослідницької діяльності.

1. Дубогай ОД, Альошина АI, Лавринюк ВС. Основні поняття й терміни здоров'язбереження та фізичної реабілітації в системі освіти: навч. посібник. Луцьк: Волинський НУ ім. Лесі Українки, $2011.296 \mathrm{c}$.

2. Круцевич ТЮ, Зайцева М. Інноваційні процеси у сфері підготовки та перепідготовки кадрів 3 фізичної культури. Теорія і методика фізичного виховання і спорту. 2005; 4: 41-4.

3. Москаленко Н, Ковров Я, Алфьоров О. Підготовка спеціалістів з фізичної культури і спорту до інноваційної діяльності. Спортивний вісник Придніпров'я. 2014; 2: 108-112.

4. Виленский МЯ, Сафин РС. Профессиональная направленность физического воспитания студентов педагогических специальностей: уч. пособие. М.: Высш. шк., 1989. 159 с.

5. Воробйов МІ, Круцевич ТЮ. Практика в системі фізкультурної освіти: навч. посібник. К.: Олімпійська література, 2006. 192 с.

6. Драгнєв ЮВ. Професійний розвиток майбутнього вчителя фізичної культури в умовах інформаційно-освітнього простору: монографія. Луганськ: ДЗ “ЛНУ імені. Тараса Шевченка”, 2013. 475 с.

7. Матвеев ЛП. Теория и методика физической культуры: учеб. пособ. М.: Физкультура и спорт, $1991.543 \mathrm{c}$.

8. Соловйов В. Психолого-педагогічні умови підвищення готовності майбутніх викладачів фізичного виховання до педагогічної діяльності. Педагогіка і психологія професійної. освіти. 2013;3:152-161.

9. Забора АВ. Формування знань і навичок майбутніх учителів фізичної культури в процесі вивчення дисциплін “Теорія і методика фізичного виховання" і “Гімнастика з методикою викладання": автореф. ... дис. канд. наук з фіз. вих. і спорту. Львів, 2003. 24 с.

10. Лещенко ГА. Формування позитивної мотивації школярів до систематичних занять фізичними вправами: автореф. дис. Кривий Ріг, 2002. 18 с. 
11. Степанченко НІ. Система професійної підготовки майбутніх учителів фізичного виховання у вищих навчальних закладах [дисертація]. Вінниця; 2017: 199-215.

12. Дубовицкая ТД. Диагностика уровня профессиональной направленности студентов. Психологическая наука и образование. 2004; 2: 82-86.

13. Наумчук ВI. Професійна підготовка майбутніх вчителів фізичної культури в процесі самостійної роботи зі спортивних дисциплін: автореф. ... канд. пед. наук. Тернопіль, 2002. 20 с.

14. Боднар АО, Юрчишин ЮВ, Стасюк II. Аналіз динаміки сформованості мотиваційного компоненту готовності майбутніх учителів фізичної культури до олімпійської освіти молодших школярів. Вісник Прикарпатського університету. Серія: Фізична культура. 2019 берез. 26; $24-5$.

15. Вацеба ОМ, Петришин ЮВ, Приступа ЄН, Боднар IP. Актуальні проблеми теорії і методики фізичного виховання: колективна монографія. Львів: Українські технології. 2005. 296 с.

16. Акусок АМ. Теоретичні засади формування змісту загальнопедагогічної підготовки майбутнього вчителя: автореф. дис. К., 2009. 21 с.

17. Чесноков АВ. Формирование профессиональных качеств педагога по физической культуре. Теория и практика физической культуры. 2001; 10: 18-21.

18. Кричфалушій MB. Готовність майбутнього спортивного педагога до науково-дослідницької діяльності. Фізичне виховання, спорт і культура здоров’я у сучасному суспільстві. 2008; 1: 192-194.

\section{References}

1. Dubogaj OD, Al'oshina AI, Lavrinjuk VE. Osnovni ponjattja j termini zdorov'jazberezhennja ta fizichnoï reabilitatsiï v sistemi osviti: navch. posibnik. Luts'k: Volins'kij NU im. Lesi Ukraïnki, 2011. 296 s.

2. Krutsevich TJu, Zajtseva M. Innovatsijni protsesi u sferi pidgotovki ta perepidgotovki kadriv z fizichnoï kul'turi. Teorija i metodika fizichnogo vihovannja i sportu. 2005; 4: 41-4.

3. Moskalenko N, Kovrov Ja, Alf'orov O. Pidgotovka spetsialistiv z fizichnoï kul'turi i sportu do innovatsijnoï dijal'nosti. Sportivnij visnik Pridniprov'ja. 2014; 2: 108-112.

4. Vilenskij MJa, Safin RS. Professional'naja napravlennost' fizicheskogo vospitanija studentov pedagogicheskih spetsial'nostej: uch. posobie. M.: Vyssh. shk., 1989. $159 \mathrm{~s}$.

5. Vorobjov MI, Krutsevich TJu. Praktika v sistemi fizkul'turnoï osviti: navch. posibnik. K.: Olimpijs'ka literatura; 2006. $192 \mathrm{~s}$.

6. Dragnev JuV. Profesijnij rozvitok majbutn'ogo vchitelja fizichnoï kul'turi v umovah informatsijnoosvitn'ogo prostoru: monografija. Lugans'k: DZ "LNU imeni. Tarasa Shevchenka", 2013. 475 s.

7. Matveev LP. Teorija i metodika fizicheskoj kul'tury: ucheb. posob. M.: Fizkul'tura i sport. 1991. $543 \mathrm{~s}$.

8. Solovjov V. Psihologo-pedagogichni umovi pidvischennja gotovnosti majbutnih vikladachiv fizichnogo vihovannja do pedagogichnoï dijal'nosti. Pedagogika i psihologija profesijnoï. osviti. 2013; 3: 152-161.

9. Zabora AB. Formuvannja znan' i navichok majbutnih uchiteliv fizichnoï kul'turi v protsesi vivchennja distsiplin "Teorija i metodika fizichnogo vihovannja" i "Gimnastika z metodikoju vikladannja" [avtoreferat. disertatsii]. L'viv, 2003. $24 \mathrm{~s}$.

10. Leschenko GA. Formuvannja pozitivnoï motivatsiï shkoljariv do sistematichnih zanjat' fizichnimi vpravami [avtoreferat. disertatsiï]. Krivij Rig; 2002. $18 \mathrm{~s}$.

11. Stepanchenko NI. Sistema profesijnoï pidgotovki majbutnih uchiteliv fizichnogo vihovannja u vischih navchal'nih zakladah [disertatsija]. Vinnitsja; 2017: 199-215.

12. 12.Dubovitskaja TD. Diagnostika urovnja professional'noj napravlennosti studentov. Psihologicheskaja nauka i obrazovanie. 2004; 2: 82-86.

13. Naumchuk VI. Profesijna pidgotovka majbutnih vchiteliv fizichnoï kul'turi v protsesi samostijnoï roboti zi sportivnih [avtoreferat. disertatsii]. Ternopil'; 2002. 20 s.

14. Bodnar AO, Jurchishin JuV, Stasjuk II. Analiz dinamiki sformovanosti motivatsijnogo komponentu gotovnosti majbutnih uchiteliv fizichnoï kul'turi do olimpijs'koï osviti molodshih shkoljariv. Visnik Prikarpats'kogo universitetu. Serija: Fizichna kul'tura. 2019 berez. 26; 24-5.

15. Vatseba OM, Petrishin JuV, Pristupa $\in N$, Bodnar IR. Aktual'ni problemi teoriï i metodiki fizichnogo vihovannja: kolektivna monografija. L'viv: Ukraïns'ki tehnologiï; 2005. $296 \mathrm{~s}$.

16. Akusok AM. Teoretichni zasadi formuvannja zmistu zagal'nopedagogichnoï pidgotovki majbutn'ogo vchitelja [avtoreferat. disertatsii]. K.., 2009. $21 \mathrm{~s}$.

18. Chesnokov AV. Formirovanie professional'nyh kachestv pedagoga po fizicheskoj kul'ture. Teorija i praktika fizicheskoj kul'tury. 2001; 10: 18-21.

19. Krichfalushij MV. Gotovnist' majbutn'ogo sportivnogo pedagoga do naukovo-doslidnits'koï dijal'nosti. Fizichne vihovannja, sport i kul'tura zdorov'ja u suchasnomu suspil'stvi. 2008; 1: 192-194. 
Цитування на цю статтю:

Черненко СО, Олійник ОМ, Сорокін ЮС, Коваль ОБ. Дослідження освітнього процесу підготовки майбутніх викладачів за спеціальністю “Фізична культура і спорт”. Вісник Прикарпатського університету. Серія: Фізична культура. 2020 Листоп 24; 36: 86-94

\begin{tabular}{|c|c|}
\hline Відомості про автора: & Information about the author: \\
\hline $\begin{array}{l}\text { Черненко Сергій Олександрович - кандидат наук } 3 \\
\text { фізичного виховання та спорту, доцент, Донбаська } \\
\text { державна машинобудівна академія (Краматорськ, } \\
\text { Україна) }\end{array}$ & $\begin{array}{l}\text { Chernenko Sergiy Oleksandrovych-Candidate of } \\
\text { Science (Physical Education and Sport), Associate } \\
\text { Professor (Ph. D.), Donbas State Engineering Aca- } \\
\text { demy (Kramatorsk, Ukraine) }\end{array}$ \\
\hline \multicolumn{2}{|l|}{$\begin{array}{l}\text { e-mail: chernenko.sergey65@ukr.net } \\
\text { https://orcid.org/0000-0001-9375-4220 }\end{array}$} \\
\hline $\begin{array}{l}\text { Олійник Олег Миколайович - старший викладач, } \\
\text { завідувач кафедри фізичного виховання і спорту, } \\
\text { Донбаська державна машинобудівна академія } \\
\text { (Краматорськ Україна) }\end{array}$ & $\begin{array}{l}\text { Oliynyk Oleh Mykolayovych - lecturer, Donbas State } \\
\text { Engineering Academy (Kramatorsk, Ukraine). }\end{array}$ \\
\hline \multicolumn{2}{|l|}{$\begin{array}{l}\text { e-mail: olegoliynyk@ukr.net } \\
\text { http://orcid.org/0000-0002-9197-1034 }\end{array}$} \\
\hline $\begin{array}{l}\text { Сорокін Юрій Серхійович - старший викладач, } \\
\text { Донбаська державна машинобудівна академія } \\
\text { (Краматорськ Україна) }\end{array}$ & $\begin{array}{l}\text { Sorokin Yuriy Serhiyovych - lecturer, Donbas State } \\
\text { Engineering Academy (Kramatorsk, Ukraine) }\end{array}$ \\
\hline \multicolumn{2}{|l|}{$\begin{array}{l}\text { e-mail: ur.sorokin65@ gmail.com } \\
\text { http://orcid.org/0000-0001-5185-5111 }\end{array}$} \\
\hline $\begin{array}{l}\text { Коваль Олег Борисович - викладач фізичного ви- } \\
\text { ховання, гімназія "Інтелект" (Дружківка, Україна) }\end{array}$ & $\begin{array}{l}\text { Koval Oleg Borysovych - lecturer, high school } \\
\text { "Intellect" (Druzhkivka,Ukraine) }\end{array}$ \\
\hline $\begin{array}{l}\text { e-mail: yevgenkoval20@ gmail.com } \\
\text { http://orcid.org/0000-0003-1257-6966 }\end{array}$ & \\
\hline
\end{tabular}

УДК 796.155.9

doi: 10.15330/fcult.36.94-101

\section{Василь Хлопецький, Сергій Курилюк, Андрій Мельник, Олена Мельник}

\section{ПРОФЕСІЙНЕ САМОВИЗНАЧЕННЯ ТА ВМОТИВОВАНІСТЬ ДО РУХОВОЇ АКТИВНОСТІ СТУДЕНТОК ПЕДАГОГІЧНИХ СПЕЦІАЛЬНОСТЕЙ}

Мета. 3'ясувати вмотивованість студенток педагогічних спечіальностей до занять фізичною культурою. Методи. В роботі використані: теоретичний аналіз, психологічні та педагогічні методи дослідження, анкетування. Результати. 3'ясовано, щуо понад 50 \% студенток задоволені своїм професійним вибором. Вони мають чіткий намір оволодіти обраним фахом; хочуть у майбутньому здійснювати діяльність по професї та удосконалюватися у вибраному напрямку; знаходять час для занять справами, які стосуються обраної професії; прагнуть мати колег у обраній сфері; виділяють свою професію серед інших. Високий рівень інтересу до занять фізичною культурою виявили 20,93\% студенток, 32,95\% - високий, 25,19\% - середній, низький - 11,4, а 9,69\% такоӥ иікавості не мають. Найбільш поширеними мотивами до занять фізичною культурою для студенток є зміцнення здоров'я (98,84 \%), поліпшення власної фізичної підготовленості (84,50\%) i покращення тіло будови (41,86 \%). Висновок. Основними причинами, які є перепоною для занять фізичною культурою є дефіцит часу $(51,55 \%)$, поганий стан здоров'я (20,54\%), відсутність спортивних секцій, які б їх зацікавили (11,24\%), спортивної інфраструктури (4,65\%), партнерів для занять фізичними вправами (10,85\%), спортивного одягу і взуття $(9,69 \%)$.

Ключові слова: фізична культура, студентки, мотиви.

The aim. To find out the motivation of students of pedagogical specialties to physical education classes. Methods. The paper uses: theoretical analysis, psychological and pedagogical research methods, questionnaires. Results. It was found that more than 50\% of female students are satisfied with their professional choice. They have a clear intention to master the chosen profession, because they like it; want in the future by profession and to improve in the chosen direction; find time to do things related to the chosen profession; seek to have colleagues in the chosen field; distinguish their profession among others. A high level of interest in physical 